\title{
Ольга ШЛЕМКО
}

\section{ЛЕСЬ КУРБАС І ГУЦУЛЬСЬКИЙ ТЕАТР}

У статті досліджено праию Леся Курбаса в Гуиульському театрі, створеному Г. Хоткевичем 1910 р. в Галичині, у гуиульському селі Краснойллі.

Вперше в українському театрознавстві встановлено часові межі перебування Л. Курбаса в Гуиульському театрі, з'ясовано його функиіональні обов'язки, уточнено деякі факти творчої біографії, до акторської скарбнииі мития додано нові ролі, спростовано недостовірну та перекручену інформацію про нього, залучено нові джерельні матеріали.

Ключові слова: Лесь Курбас, Гуиульський театр, вистава, актор, режисер, організатор глядача.

В статье проведено исследование работы Леся Курбаса в Гуиульском театре, созданном Г. Хоткевичем в 1910 г. в Галиции, в гучульском селе Красноилье. Впервые в украинском театроведении установлены временные рамки пребывания Л. Курбаса в Гуиульском театре, выяснены его функииональные обязанности, уточнены некоторые факты творческой биографии, в актерскую копилку художника добавлены новые роли, опровергнуто недостоверную и искаженную информацию о нем, привлечены новые источники.

Ключевые слова: Лесь Курбас, Гуиульский театр, спектакль, актер, режиссер, организатор зрителя.

In the article, Les Kurbas work at the Huzul Theatre, which was created by G. Khotkevych in 1910 in the Huzul village Krasnoillia (Galicia), is analysed. For the first time in the theatre criticism, the terms of Les Kurbas's work in the Huzul Theatre are found out. The author considers the duties of Les Kurbas there. Some facts of his creative biography are detailed. The author lists up the new roles of the director and refutes the distorted information about him. The new materials, concerned Les Kurbas's creativity are highlighted.

Key words: Les Kurbas, Huzul theatre, performance, actor, director, organizer of an audience.

Особливе місце у творчому житті Леся Курбаса посідає праця в Гуцульському театрі, створеному Г. Хоткевичем 1910 р. в Галичині, у гуцульському селі Красноїллі. Цей театр став мистецьким та етносоціокультурним феноменом не лише українського, а й світового театрального мистецтва. Однак дослідники називають різні дати початку і завершення праці митця в Гуцульському театрі, по-різному описують його функціональні обов'язки. 3'ясування початків творчої діяльності Л. Курбаса, пов'язаної з Гуцульським театром, дасть можливість створити цілісний портрет митця, краще зрозуміти феномен потужного вибуху його режисерського таланту.

Праця Л. Курбаса в Гуцульському театрі тією чи іншою мірою відображена у публікаціях Г. Хоткевича, М. Рудницького, Т. Водяного, Й. Гірняка; у листах О. Панасевича-Ремеза, Й. Гулейчука; у публікаціях П. Хоткевич, Р. Пилипчука, М. Лабінського, В. Стеф'юка, С. Чорнія, М. Шудрі, I. Волицької, П. Медведика, Ю. Бобошка, Н. Кузякіної,
В. Шлемка, В. Ревуцького, П. Арсенича, А. Болабольченка, Р. Кирчіва, О. Шлемко, О. Василишин. Хоча деякі автори обмежились лише побіжною згадкою про цей період діяльності, ми задля з'ясування істини все ж таки розглянемо їхні міркування. Безперечно, важливі для нас і свідчення самого Л. Курбаса.

Мета статті - здійснити реконструкцію творчого життя Леся Курбаса, пов'язаного з Гуцульським театром, 3'ясувати його функціональні обов'язки, дати початку і завершення праці в цьому театрі, спростувати недостовірну та перекручену інформацію про митця, уточнити деякі факти його творчої біографії, залучити нові джерельні матеріали.

Як свідчить сам Г. Хоткевич у «Спогадах 3 театральної діяльності», Л. Курбас з'явився в Гуцульському театрі у зв'язку з ситуацією, що виникла на самому початку гастрольної подорожі, яка почалася 26 листопада 1911 р.: «<... я сильно був затурбований відсутністю директора, бо 
Ремез чи й спочатку не був, чи мав куди виїхати, вже не пам'ятаю, але з Гуцульським театром їхати не міг. Я шукав директора. Питався близьких до театральних справ людей - кого би можна закликати на ту посаду. Мені вказали на молодого актора, ім'я якому... Курбас» [33, 564-565]. І далі з властивим йому гумором Г. Хоткевич пише: «Він і тоді був Курбас, але не Курбас, а просто собі молодий актор Курбас. Переговори велися, але не пам'ятаю, до якого скутку вони дійшли. Здається, приїхав Курбас і трохи вів справу, але не пам'ятаю добре» $[33,565]$. Постає питання: йдеться про приїзд Л. Курбаса ще наприкінці листопада чи у грудні 1911 р.? А що про це можна довідатись із інших розвідок?

Цінними $€$ для дослідження Гуцульського театру публікації Платоніди Хоткевич. У статті «3 історії Галицького театру (Гуцульський театр p. 1911-1914)», опублікованій у львівському місячнику «Наші дні» (1943 р., № 11), П. Хоткевич стверджує, що тоді, коли «гуцули добрались до Харкова, Москви, побували в Одесі», режисером Гуцульського театру був «вже не Ремез, а Лесь Курбас» [34]. Таке твердження безпідставне, оскільки Л. Курбас покинув Гуцульський театр у 1912 р., а гастрольні виступи в Москві та Одесі відбулись у $1914 \mathrm{p}$.

М. Рудницький, сучасник Л. Курбаса, перший у повоєнний період у своїй книжці «В наймах у Мельпомени» (1963) висловився про Л. Курбаса в контексті Гуцульського театру. Це й не дивно, адже йому, як носієві цієї інформації, не потрібно було розшукувати іiї десь в архіві. Хоча його спогади й позначені літературною фантазією, все ж наведемо деякі фрагменти: «Студента Курбаса ми майже не знали у Львові. Коли ж він повернувся з Відня в $1904(1908$ p. - O. $U)$ році, всі звернули увагу на те, що замість думати про вчительську посаду, Курбас провадив палкі розмови з Гнатом Хоткевичем» $[29,304]$. Письменник пояснював Л. Курбасу, «як він уявляє собі новий театр, в якому гратимуть головно гуцули. Курбас уважно прислухався і не заперечував проти ще одного експерименту. Промандрувавши півроку з Хоткевичем як актор і його учень, він повернувся у Львів» [29, 304].

Насамперед з'ясуємо, що відомо про перебування Л. Курбаса в Гуцульському театрі сучасним дослідникам. Наприклад, Р. Пилипчук, автор розділу «Театр на західноукраїнських землях» у першому томі видавння «Український драматичний театр» (1967), у параграфі про Гуцульський театр Гната Хоткевича стверджує: «На початку 1912 р. "Гуцульський театр" під керівництвом О. Ремеза та Л. Курбаса здійснив свою другу подорож по Галичині, на цей раз - 3 новою програмою» [26, 437]. Насправді згаданий театр $з$ новою програмою здійснив свою гастрольну подорож восени 1911 p., а точніше, з 26 листопада.

У спогадах Т. Водяного, вміщених у збірнику «Лесь Курбас: Спогади сучасників» (1969) йдеться про те що «навесні 1912 року Курбас вступив до Гуцульського театру» $[8,68]$. Натомість М. Лабінський у примітці до наведеного вище твердження Т. Водяного помилково зазначив: «За останніми даними Л. Курбас вступив до напівпрофесіонального Гуцульського театру у 1910 р. (див. «Український драматичний театр», т. 1, К., видво АН УРСР, стор. 435) [8, 68]. Тобто при цьому він безпідставно послався на згадану публікацію Р. Пилипчука, хоча там така інформація відсутня.

Дослідник українського театру у діаспорі С. Чорній у своїй праці «Український театр і драматургія» (1980), не посилаючись, щоправда, на першоджерела, зокрема, стверджує: «На початку 1911 року Курбас працював у Гуцульському театрі Гната Хоткевича, а в грудні того ж року перейшов до театру "Руської Бесіди", яким керував Йосип Стадник» [35, 347]. Твердження про працю Л. Курбаса в Гуцульському театрі на початку 1911 року не відповідає дійсності, оскільки цей театр розпочав свої гастрольні подорожі аж на початку березня $1911 \mathrm{p}$.

П. Медведик, зокрема, зазначає у статті, що Л. Курбас на запрошення Г. Хоткевича «прибув 22 січня 1912 року до Станіславова, де театр розпочав гастролі після місячної відпустки. Хоткевич живе у Львові, а театр під час гастролей очолюють адміністратор Курбас і режисер Ремез. Обидва працюють у злагоді та приязні» [23, 86]. Насправді Гуцульський театр не розпочинав свої гастролі 22 січня 1912 р. у Станіславові, а, розпочавши гастрольну подорож 26 листопада 1911 р., закінчив iii 2 квітня 1912 року. Немає також документальних свідчень про вступ Л. Курбаса до театру саме у Станіславові. Л. Курбас у Гуцульському театрі виконував не лише функції адміністратора, як зазначає П. Медведик, а й грав деякі ролі у виставах. Водночас О. Ремез був не лише режисером, а насамперед директором театру.

П.Медведик пише далі: «Десь наприкінці квітня Лесь поїхав до гуцульського села Красноїлля - готував трупу до зарубіжних гастролей. У перших днях травня він поселяється у Криворівні і наполегливо продовжує почату справу, купує деякий реквізит. Захоплення гуцулами, красою карпатської весни приносило йому радість і насолоду. 
Тоді він пише листа Г. Хоткевичу про свої радощі й тривоги» $[23,87]$. Далі дослідник наводить листа, який насправді належить не Лесеві Курбасу, а Михайлові Ломацькому, про що ми поговоримо далі. Жодних документальних підтверджень щодо поїздки Л. Курбаса до Красноїлля «наприкінці квітня» не існує, тим більше про його поселення «у перших днях травня» в Криворівні та закупівлі реквізиту. Мало того, саме листи Л.Курбаса до Г. Хоткевича, уривки 3 яких ми наведемо далі i один 3 яких, до речі, цитує П. Медведик, свідчать про те, що він так і не поїхав до Красноїлля, оскільки не дістав від Г. Хоткевича ствердної відповіді щодо організації гастролей до Росії. Слід говорити не про «п'ять листів Курбаса» до Г. Хоткевича $[23,86]$, написаних весною 1912 р., як це робить П. Медведик, а про чотири (4 березня і 3 , 9 та 12 квітня 1912 р.). Не торкатимемося деяких інших неточностей та перекручень у згаданій публікації. Цінність статті П. Медведика полягає в їі грунтовності та, зокрема, у тому, що вона сперта на свідчення сучасників Л. Курбаса, з якими дослідник мав можливість розмовляти.

I. Волицька у праці «Театральна юність Леся Курбаса» спробувала, зокрема, дослідити діяльність Л. Курбаса в Гуцульському театрі. 3 цього приводу вона стверджує: «На початку 1912 року Гнат Хоткевич виїхав на Наддніпрянську Україну, щоб підготувати там гастролі Гуцульського театру. Перед від'їздом, у зв'язку з тимчасовою відсутністю Олекси Ремеза, він доручив справи театру Лесю Курбасу» $[9,85]$. Дослідниця вважає, що «десь на початку травня (1912 р. - О. Ш.) Лесь Курбас нарешті виїхав до Красноїлля, де наполегливо продовжував готувати Гуцульський театр до поїздки на Наддніпрянщину» $[9,88]$. Однак думка І. Волицької про те, що у зв'язку з тимчасовою відсутністю Олекси Ремеза, Гнат Хоткевич перед своїм від'їздом на Наддніпрянську Україну «доручив справи театру Лесю Курбасу», не знайшла підтвердження. Так само не відповідає дійсності iii твердження про перебування весною 1912 р. Л. Курбаса у Красноїллі.

Театрознавець В.Стеф'юк, який мав можливість спілкуватися з деякими акторами Гуцульського театру, а також з Платонідою Хоткевич, у статті «Лесь Курбас і Гуцульський театр», опублікованій у районній газеті «Гуцульський край» (1997, 31 трав.), відзначав: «Так, за останніми даними підтверджено, що Курбас вступив до напівпрофесійного Гуцульського театру у 1910 році». Також ми довідуємось від В.Стеф'юка, що «Гуцульський театр під опікою Олекси Ре- меза в кінці січня 1912 року виїхав у свою другу гастрольну подорож. Лесь Курбас під час тих гастролей виконував функції режисера та адміністратора театру» [32].

Насправді Л. Курбас вступив до Гуцульського театру не в 1910, а наприкінці 1911 р. Під час гастролей Гуцульського театру він виконував не лише функції режисера та адміністратора, як стверджує В. Стеф'юк, а й актора. Отже, ті кілька речень із загаданої статті В. Стеф'юка, присвячених безпосередньо перебуванню Л. Курбаса в Гуцульському театрі, не лише не розкривають заявлену в її назві актуальну тему дослідження, а через низку перекручень та недостовірних даних вводять читача в оману. На жаль, В. Стеф'юк, спілкуючись 3 гуцульськими акторами, вочевидь, не запитав їх про участь у цьому театрі Леся Курбаса. Так, у спогадах акторів Гуцульського театру, які він записав, митець узагалі не згадується.

А. Болабольченко, якого без перебільшення можна назвати біографом Г. Хоткевича, у фундаментальній праці «Гнат Хоткевич. Біографічні нариси», виданій 1996 р. і перевиданій 2008 р., але вже з листами до автора, в одній з приміток, зокрема, зазначає: «1911 року він (Лесь Курбас. O. $\amalg$.) знову їде до Відня. Навесні 1912 року повертається і вступає до Гуцульського театру. Грав у “Довбуші”. Працював з О. Ремезом, бо Г. Хоткевич з театром не подорожував і скоро виїхав до Києва» $[6,112]$. Слід зауважити, що Л. Курбас вступив до Гуцульського театру не весною 1912 р., як зазначає А. Болабольченко, а наприкінці 1911 p.

На жаль, краєзнавець П.Арсенич у праці «Гуцульщина у творчості Гната Хоткевича» (2000) не визначає часових меж перебування Л. Курбаса в Гуцульському театрі і не вписує його в контекст цього театру, а обмежується короткою фразою: «Артист і режисер Гуцульського театру, пізніше видатний актор, режисер і теоретик українського театру» $[1,33]$. У статті П. Арсенича під назвою «Дорога на вершину творчості починалася з Гуцульського театру», присвяченій праці Л. Курбаса в Гуцульському театрі, власне лише одним реченням сказано про перебування митця в цьому театрі: «В першій половині 1912 року Лесь Курбас — адміністратор і режисер "Гуцульського театру" Гната Хоткевича» [3]. Тож краєзнавець П. Арсенич, як і згадуваний уже театрознавець В. Стеф'юк, маючи можливість спілкуватися $з$ деякими акторами Гуцульського театру Г. Хоткевича, не поцікавився у них, яким вони запам'ятали Л. Курбаса.

Р. Кирчів у статті «Унікальне явище Українського народного театру (до 90-річчя заснуван- 
ня Гуцульського театру)» зазначає: «В лютому 1912 р. Хоткевич виїхав до Росії, не пориваючи зв'язку зі своїм театром (Гуцульським театром $O$. $U$.) і плекаючи намір підготувати там поїздку гуцулів на Наддніпрянщину. Перед від'ізздом він залучив до керівництва театром молодого Леся Курбаса, який у той час робив свої перші кроки на сцені» $[14,146]$. Тобто Р. Кирчів вважає, що Л. Курбас з'явився в Гуцульському театрі десь на початку 1912 р.

Варто навести також деякі енциклопедичні видання, де згадується про участь Л. Курбаса в Гуцульському театрі. Так, уперше згадка про це 3'явилась друком в «Українській загальній енциклопедії "Книга знання"» (1932) за редакцією Івана Раковського. У ній, зокрема, зазначено, що Л. Курбас «вперше виступив у гуцульському театрі Гн. Хоткевича, опісля працював у львівському театрі “Бесіди”, далі в театрі М. Садовського» [20, 420-421]. Тобто часові межі праці Л. Курбаса в згаданому театрі не вказано. До того ж таке твердження не відповідає дійсності, бо до Гуцульського театру Л. Курбас уже встиг попрацювати актором в аматорському театрі при Товаристві «Сокіл» та режисером у студентському театрі.

У третьому томі «Театральної енциклопедії», виданому 1964 р. в Москві, у статті Римми Барнацької про Леся Курбаса повторено хибну інформацію з 7-го тому УРЕ: «Закінчив історико-філологічний ф-т Віденського університету (1909). Того ж року почав сценічну діяльність у гуцульському театрі Г. Хоткевича» $[4,337]$. А проте факт появи інформації про Л. Курбаса в радянському енциклопедичному виданні у 60 -х роках XX ст. після тривалого замовчування мав, безперечно, позитивне значення.

Автор статті про Гуцульський театр у 2-му виданні Української радянської енциклопедії (1979) Р. Пилипчук, зокрема, зауважує: «Під час гастролей театр очолювали О. Ремез (1911-1912), Л. Курбас (1912)» [25, 223]. Насправді директором Гуцульського театру був О. Ремез. Тож Л. Курбас міг виконувати обов'язки керівника театру лише за умов відсутності з якихось причин О. Ремеза.

Знаменною подією, яка мала б заповнити «білі плями» в творчій біографії Л. Курбаса цього періоду, мав би стати параграф «Гуцульський театр Гната Хоткевича» в другому томі «Історії українського театру», виданому 2009 р. Інститутом мистецтвознавства, фольклористики та етнології ім. М. Т. Рильського НАН України. Насправді цей параграф мав дещо дивну і науково необгрунтовану назву «Діяльність трупи Товариства
“Руська бесіда" в Галичині. Гуцульський театр Гната Хоткевича», а його авторами були позначені Р. Пилипчук і П. Арсенич [27, 147-155]. У розмові 3 автором цих рядків Р. Пилипчук категорично заперечив свою причетність до згаданого тексту та членство в редколегії тому. Вочевидь, згадка про цей факт у моїй статті «Театральні університети Леся Курбаса», вміщеній у виданні «Записки НТШ. Праці Театрознавчої комісії» (2012 р.) мала певний резонанс, оскільки через деякий час другий том «Історії українського театру» дивним чином «перевидали». Однак «перевиданий» том виявився ідентичний попередньому, за винятком зміни назви згаданого параграфа 1.3.3., який став називатись «Гуцульський театр Гната Хоткевича» $[2,147-155]$, тобто позбувся зайвого «баласту» у вигляді театру Товариства «Руська бесіда», діяльності якого було приділено лише два коротких речення (!).

На жаль, текст згаданого параграфа, автором якого залишився лише П. Арсенич, породив більше запитань, ніж дав відповідей. Тож $з$ цієї праці, яка претендує на те, щоб стати авторитетним джерелом, ми довідуємось, що «усі спектаклі Гуцульського театру впродовж першої половини 1912 р. йшли під безпосереднім наглядом режисерів Леся Курбаса, а згодом і Олексія (Олекси - О. ШШ.) Ремеза, на що Чарнецький звернув увагу» $[2,152]$. По-перше, С. Чарнецький ні у своїх рецензіях, ані в параграфі про Гуцульський театр у своєму «Нарисі історії українського театру в Галичині» (Львів, 1934) не згадував прізвища Л. Курбаса в контексті Гуцульського театру, а по-друге, незрозуміло, з яких джерел узято інформацію, що спочатку режисерський нагляд здійснював Л. Курбас, а вже згодом О. Ремез. Принаймні ці домисли не підтверджує жодне джерело. Далі довідуємося, що «окрім О. Ремеза, у театр прийшов на ролі й режисуру Лесь Курбас, який підготував нову програму для колективу, розробляв режисерські експлікації для постановки творів української драматургії» [2, 152]. Знову ж таки домисли, оскільки Л. Курбас жодної нової програми для колективу Гуцульського театру не готував і жодної експлікації для постановок творів української драматургії не мав сенсу розробляти, позаяк у цьому театрі йшли лише гуцульські п'єси Г. Хоткевича, які поставив сам драматург.

У контексті гастрольної подорожі частини колективу Гуцульського театру в Москву П. Арсенич раптом зазначає: «Режисери Г. Хоткевич, О. Ремез, Лесь Курбас не нав'язували акторам строгих мізансцен, уникали тривалих монологів, 
показної театральності, які знівелювали б естетичну суть театру» $[2,154]$. По-перше, ні О. Ремез, ні Л. Курбас на гастролі з групою гуцульських артистів в Москву не виїздили, а по-друге, згадані троє митців не були в Гуцульському театрі рівноправними режисерами, як це випливає зі змісту фрази, а кожен мав свої чітко визначені функціональні обов'язки. Зрештою, ми вказали лише на ті перекручення і недостовірні дані, що стосуються безпосередньо Л. Курбаса, насправді їх у цій невеликій за обсягом статті набагато більше, не кажучи вже про відсутність театрознавчого підходу у викладенні матеріалу.

Отже, початок праці Л. Курбаса в Гуцульському театрі, визначений згаданими сучасними дослідниками, коливається в межах 1910 - весна 1912 pp. Натомість завершення праці Л. Курбаса в цьому театрі сягає кінця першої половини 1912 p.

Важливу інформацію повідомив видатний український актор Йосип Гірняк, який дуже яскраво змалював своє перше враження від гастролей Гуцульського театру в Тернополі, котрі, як з'ясовано, відбулися 23 травня 1911 р., та від молодого Л. Курбаса, якого спочатку випадково побачив на Панській вулиці біля рекламної афіші місцевого кінотеатру. На вечірній виставі «Верховинці» (під такою назвою виставлялася п'єса Г.Хоткевича «Антін Ревізорчук») Гуцульського театру він побачив актора Л. Курбаса у заголовній ролі Антося Ревізорчука. Особливо вразила Йосипа блискуча гра Л. Курбаса у фінальній сцені вистави: «О, як він заридав біля ніг покійної матері! Як услід за ним заголосили гуцули на сцені. Зал принишк, i, здавалось, ось-ось заридає вся зала тернопільських театралів. Завіса опустилася і закрила ту трагічну сторінку карпатської сім'ї. Глядачі щиро дякували артистам i, зворушені, стали виходити із зали театру» $[11,18]$. Після вистави Й. Гірняк ще раз побачив Л. Курбаса в «товаристві старшого пана, що налягав на ногу» $[11,18]$. Без сумніву, це був Г. Хоткевич, котрий, як відомо, мав саме таку фізичну ваду і доволі рідко виїздив зі Львова на гастрольні вистави Гуцульського театру. Його присутність у Тернополі викликана принаймні двома причинами: а) хворобою М. Сінітовича як виконавця ролі Антося Ревізорчука та директоpa i режисера театру О. Ремеза; б) потребою введення Л. Курбаса на роль Ревізорчука. На жаль, у своїх «Споминах», виданих 1982 р. у Нью-Йорку, Й. Гірняк не називає ні року, ні місяця, коли він бачив Л. Курбаса у виставі Гуцульського театру.

В. Ревуцький у книжці «Нескорені березільці: Йосип Гірняк і Олімпія Добровольська», спираю- чись на згадані «Спомини» Й. Гірняка, стверджує: «Коли Йосипові було 15 років, він відвідував у Тернополі вистави Гуцульського театру під керівництвом Гната Хоткевича і мав змогу бачити на сцені молодого Леся Курбаса, який назавжди заворожив його» $[29,10]$. Відомо, що Гуцульський театр побував в Тернополі двічі: у травні 1911 р. і наприкінці березня 1912 р. Однак, оскільки виставу «Верховинці» цей театр показав лише 23 травня 1911 р., то виходить, що Й. Гірняк бачив саме цю виставу.

Свідчення такого поважного автора, як Й. Гірняк, і підтримка цього свідчення у В. Ревуцького - такі відомості до кінця 80-х років ХХ ст. були недоступні в радянській Україні, тому ніхто 3 тогочасних дослідників творчості Л. Курбаса не вписав у його акторську скарбницю роль Антося Ревізорчука. Про це вперше заговорила авторка цієї статті. Наведений спогад Й. Гірняка дає підстави стверджувати, що Лесь Курбас прийшов у Гуцульський театр в останній декаді травня 1911 р., але ще не як «штатний» працівник, а як «разовий гастролер», для заміни хворого Михайла Сінітовича - виконавця ролі Антося у виставі «Верховинці».

Що ж до другого приходу Л. Курбаса в Гуцульський театр, то тут маємо різні припущення. Директор і режисер Гуцульського театру Олекса Ремез (1882-1961), політичний емігрант з Наддніпрянської України, в листі з Одеси до Ф. Погребенника від 8 травня 1959 р. повідомляє: «Курбас прийшов до "Гуцульського театру" на другому році існування театру. Прийшов безпосередньо по закінченні Віденського університету і театральної студії при Віденській консерваторії. Режисурою Курбас не займався, а працював на посаді актора в ролі попа у п’єсі Хоткевича “Довбуш”. Літом 1912 р. Гуцульський театр на жнива вернув домів. Курбас зараз же вступив до Львівського театру "Української бесіди" <...>» [24]. Що означає «на другому році існування театру»? Якщо відправною точкою вважати не весну 1910 р., коли нібито молодь гуцульського села Красноїлля запросила Г. Хоткевича очолити їхній аматорський гурток, а першу виставу «Верховинців», яка відбулася у першій половині серпня 1910 р., то перший рік буде від серпня 1910 до серпня 1911 р., а другий — від серпня 1911 до серпня 1912 p.

Таким чином 3 листа О.Ремеза від 08.05.1959 р. ми довідуємося про кілька дуже важливих моментів: по-перше, Л. Курбас вступив до Гуцульського театру після закінчення навчання у Віденському університеті і театральній студії при 
Віденській консерваторії; по-друге, він працював як актор у ролі священика у виставі «Довбуш». На жаль, О. Ремез чомусь не згадує, що Л. Курбас грав роль Антося Ревізорчука у виставі «Верховинці» Ю. Коженьовського, — може, він не був тоді у Тернополі, якщо був особисто присутній сам Г. Хоткевич. 3 цього листа О.Ремеза також випливає, що Л. Курбас побував з Гуцульським театром в його останній, четвертій, гастрольній подорожі, яка розпочалася 17 травня 1912 р. і завершилася влітку. Поки що це повідомлення не знайшло документального підтвердження.

У лютому 1912 р. під час гастрольної подорожі по Галичині, О. Ремез надіслав Г. Хоткевичеві звіт передовика (тобто організатора гастролей перед прибуттям театру до відповідного населеного пункту) театру Г. Гарасим'юка, який заявив про свій вихід з театру, а на звороті звіту О. Ремез зазначив, що останнього «замінити ніким, Курбас помагає, але хорує, від того і дістає відразу» [28]. Тобто ми довідуємось, що Л. Курбас у лютому 1912 р. допомагає організовувати вистави.

Важливу для нас інформацію про Л. Курбаса можемо довідатись від Йосифа Гулейчука, який був найвідданішим помічником Гната Хоткевича $\mathrm{i}$, властиво, співзасновником Гуцульського театру. Так, Й. Гулейчук у листі до Г. Хоткевича від 11.04.1912 р. стверджує: «Курбас взяв "Прах. [тикованого] жовніра", то може розпише ролі, писав, що сего тижня виїде (зі Старого Скалата. O. Ш.)» [12]. Він висловлює свої міркування 3 приводу місця проведення репетицій і сподівається, що в Коломиї і Жабйому можна було б дати "Прахтикованого жовніра", однак його непокоїть, чи вдасться полагодити справу з “цинзуров та 3 концесійов”» [12]. Й. Гулейчук також висловлює своє незадоволення роботою попереднього передовика Гарасим'юка, який не забезпечив належної організації вистав, завдав театрові збитки, а сам «пішов без “будьте здорові”. Зі Львова до Золочева, Тернополя, Бережан пішов Курбас з 30 коронами і приготовив усе, що треба було» [12]. Тобто Л. Курбас, власне кажучи, зарадив лиху, зумівши ціною неймовірних зусиль, 3 обмаллю грошей організувати подальші виступи театру. Це свідчення Й. Гулейчука дає підстави додати до таких функцій Л. Курбаса в Гуцульському театрі, як актор і режисер, ще й обов'язки передовика, тобто організатора глядача.

На участь Л. Курбаса в Гуцульському театрі проливають світло насамперед його листи до керівника цього театру Г. Хоткевича, який у лютому 1912 р. виїхав з Галичини і оселився з сім'єю у
Києві, де поліція одразу ж встановила за ним негласний нагляд. Організаційні заходи Г. Хоткевича щодо перевезення Гуцульського театру в межі Російської імперії були перервані 3 квітня 1912 p. несподіваним обшуком у його помешканні та арештом. Письменника 24 квітня було відправлено етапом до Харкова, де він утримувався у пересильній тюрмі разом з кримінальними злочинцями і лише на початку червня 1912 р., після зняття обвинувачення, зміг повернутися до Києва.

М. Шудря і М. Лабінський помилково приписують Л. Курбасові один з листів М. Ломацького, написаний, на їхню думку, восени 1911 р. в селі Ілем’ї [13, 28-29], і вміщують його в журналі «Соціалістична культура» (1987, № 2). Також П. Медведик помилково вважає Л. Курбаса автором згаданого листа, написаного, на його думку, у травні 1912 p. [23, 87], і оприлюднює лист у своїй статті, надрукованій у журналі «Жовтень» (1987, №5). Згодом до такої ж думки пристала I. Волицька, яка вмістила лист, що його написав, як вона помилково вважає, Лесь Курбас приблизно у травні 1912 р. [9, 88-89], до своєї праці «Театральна юність Леся Курбаса...». Аналіз змісту листа та почеркознавчий аналіз дав нам можливість ідентифікувати його як лист учителя, письменника i громадсько-культурного діяча Михайла Ломацького (1886-1968), написаний до Г. Хоткевича десь на початку 1914 р. [22].

Перший відомий нам лист Л. Курбаса до Г. Хоткевича датований 4 березня 1912 р. У цьому листі, написаному під час гастролей Гуцульського театру у Городку Ягеллонському (тепер м. Городок, районний центр у Львівській області), Л. Курбас виступає проти призначення актора Фодчука передовиком театру, оскільки вважає, що той, хоч і дуже симпатична людина, «передовсім - страшенний мамалига». Водночас адресант звертає увагу Г. Хоткевича, що «з цим, як тепер грається (головно масові сцени), неможливо буде нікуди в світ показатись. В дорозі важко те виправити. Скільки разів я сам чув навчання Ремеза - а все однако грають. Треба б, щоб Ви побували з нами в Красноїлі, і конче треба б хоч трохи залеглостий в людий виплатити» [18]. Тобто Лесь Курбас переймається великою заборгованістю театру перед гуцульськими акторами.

У наступному листі від 3 квітня $1912 \mathrm{p}$. Л. Курбас повідомляє керівника Гуцульського театру: «Ваш лист одержав і застосовуюсь у всім до поданих у ньому вказівок. По-перше, пишу. А далі - на святах я дома, а кілька днів після Великодня їду до Красноїлі. Не знаю лише, чи швидко 
дасться діло поладнати. Дуже вже втомлені їхали люди домів, похоровані (з Ремезом, що поважно хорий - до 7 душ), та найважніше - 3 обмалью гроший <...>» [17]. Л. Курбас переймається тим, що гуцульським акторам не виплачено заборгованого. Ця остання для Леся Курбаса гастрольна подорож з Гуцульським театром виявилася надзвичайно важкою. Театр зазнав матеріальних збитків, багато акторів були виснажені та хворі, люди висловлювали невдоволення з приводу заборгованої їм платні. «3 трупою я, як писав вже Вам, поїду дуже радо, — провадив далі Л. Курбас. — Не знаю, чи писав Вам Ремез, що Лазар Шевченко (тепер у Єйську, у Прохоровича) хотів би обняти провід нашим театром гуцульським під час російського турне. Пишу про те 3 морального обов'язку, бо д[обродій] Шевченко все ж - російський уродженець і старий актор» [17]. Курбасова аргументація ще раз свідчить про його неприховане прагнення очолити гастролі Гуцульського театру до Росії. Насамкінець Л. Курбас зазначає: «Напишу вже аж 3 Красноїлі про перші “успіхи”» [17]. Одразу ж після великодніх свят 1912 р. він планував поїхати в Красноїлля, щоб дібрати нових гуцульських артистів і провести репетиції вистав.

Листа від 9 квітня 1912 р. Л. Курбас знову ж таки пише не з Красноїлля, а зі Старого Скалата. Можливо, що перед тим він отримав ще одного листа від Г. Хоткевича, який не додав йому оптимізму щодо майбутніх гастролей до Росії. Насамперед Л. Курбас питає: «Якщо треба Вам подавати його (примірник п'єси «Прахтикований жовнір» - $O$. $W$.) до російської цензури, то прошу написати мені, а я його якось перепишу і надішлю Вам оригінал. До Красноїлі думав я їхати на сьому тижні, але Ваше "не знаю як ліпше" і " $є$ ще час" забило мені цьвяха в голову: Бо й справді - якщо справа має протягнутись на місяць - півтора, то там таки не буде що робити тепер. А поки я не знатиму, як Ви думаєте урегулювати матеріяльний бік діла, кому Ви думаєте повернути гроші зараз, а кому ще ні < ..> поки я того всего не знаю, то не маю ніяких підстав, на яких міг би організувати, т. є. стисло - вербувати < ..> Тому, думаю, - найкраще буде, як я зажду тут, у себе дома, аж поки ви, зміркувавши, що в Росії поладналось усе в нашу користь - не дасте мені знаку — їхати. I ще прошу мені описати ті “основи вербунку”» [19]. Л. Курбас натякає про власний намір очолити гастрольну поїздку Гуцульського театру до Росії. Це дало б йому можливість вирватися із задушливої атмосфери Галичини і пов'язати свою творчу діяльність з Наддніпрянською Україною.
В останньому відомому нам листі зі Старого Скалата до Г. Хоткевича в Київ, датованому 12 квітня 1912 р., Л. Курбас подає короткий виклад листа Й. Гулейчука 3 Красноїлля, який, зокрема, повідомляє: «Найшов багато нових, гарних хлопців, ще бракує дівчат, бо з старих здаєси лишитси кілька. Не знаю чи не взяти яких панєн, тих, що зголошувались, аби лиш по гуцульськи перебрались» [16]. Л. Курбас одразу коментує: «<...> мені здаєсь, що це було б не доцільно їх брати» [16]. Це свідчить про Курбасове розуміння того, що унікальність Гуцульського театру криється насамперед у самобутності автентичних гуцулів. Далі він знову цитує листа Й. Гулейчука: «Донині нічо не маю ще від Хоткевича, не знаю, що $є$, чи там що зроблено, коли можна вирушити, бо довго чекати буде зле, люди розійдуться в роботу, тут поплатна робота на всі боки» [16]. Водночас Л. Курбас зазначає: «І взагалі мені самому було б дуже важно і цікаво знати, чи $є$ вже тепер яка-небудь приблизна певність щодо часу нашого виїзду до Росії. А якщо $\epsilon$, то коли мав би цей історичний факт задивувати світ?» [16]. Далі Л. Курбас наголошує: “Якщо самі що-небудь про це знаєте, то при нагоді напишіть, бо мені треба б поладнати деякі домашні справи, а спосіб їх поладнання якраз зависить від часу мого виїзду». Насамкінець Л. Курбас ледь не волає: «Чекаю знаку од Вас з тугою, бо вдома скучно страшно - от Поділя. Хотів би вже в гори їхати. Страх як хотів би. А передчасом їхати може не "політично"» [16].

Однак Л. Курбас, не дочекавшись від Г. Хоткевича позитивної відповіді або й дізнавшись про його арешт, а отже й крах своїх надій на виїзд разом 3 театром до Росії, змушений був шукати інший варіант застосування свого творчого потенціалу. Тож незабаром Л. Курбас уже в Руському народному театрі Товариства «Руська бесіда», куди його взяв керівник цього театру Й. Стадник і де він швидко зарекомендував себе як талановитий, різноплановий актор, продовживши сімейну традицію, яку започаткували його батьки - талановиті галицькі актори Степан та Ванда Яновичі.

Наостанок звернемось до своєрідної альма-матер митця, а точніше, меморіального музеюсадиби Л. Курбаса, де минули його дитячі роки і звідки, до речі, він написав Г. Хоткевичу згадані чотири листи (4 березня і 3, 9 та 12 квітня 1912 р.). Так, директор музею-садиби Леся Курбаса О. Василишин переконана, що митець працював у Гуцульському театрі з 22 січня по квітень 1912 року «на посаді адміністратора» [7, 28], тоб- 
то, власне кажучи, повторює думку П. Медведика $[23,86]$, однак це не відповідає дійсності. Не має документального підтвердження й інше іiі твердження: «Десь наприкінці квітня Лесь поїхав до гуцульського села Красноїлля - готував трупу до зарубіжних гастролей. У перших днях травня він поселяється у Криворівні і наполегливо продовжує почату справу, купує деякий реквізит» [7, 29]. Тут знову ж таки слово в слово повторено твердження П. Медведика [23, 87]. Директорка музеюсадиби Л. Курбаса запевняє: «Багато зусиль і пошуків затрачено, щоб встановити, чим займався Л. Курбас із січня 1911 р. до вересня 1912 р., тобто більше ніж півтора року», проте знову ж таки цитує П. Медведика, який справді немало зробив, щоб з'ясувати деякі факти з творчої біографії Л. Курбаса. Тим часом у музеї, вочевидь, самостійно не досліджували цей період творчої діяльності Л. Курбаса, а тому його працівникам непросто зорієнтуватися у морі суперечливої інформації.

Театрознавцеві Майі Гарбузюк вдалося документально встановити і оприлюднити у статті «Початок професійної акторської діяльності Леся Курбаса: до проблеми датування», надрукованій у журналі «Просценіум» (2012, № 1-3), інформацію про те, що Л. Курбас вперше з'явився на сцені театру Товариства «Руська бесіда» 6 червня 1912 р. в ролі Нептуна у прем’ерному показі комічної опери «Еней на мандрівці» Я. Лопатинського [10, 5]. Однак публікація М. Левицького у газеті «Нова Буковина» від 16.06.1912 р. свідчить про те, що прем'єра згаданої опери відбулася не 6, а 4 червня 1912 р. [21]. Анонс про прем'єру цієї опери в Чернівцях, щоправда не 4, а 3 червня, з'явився в газеті «Нова Буковина» 31 травня 1912 р. Однак театр не був готовий виставити оперу 3 червня. Очевидно, що 4 червня роль Нептуна також виконував Л. Курбас. Отже, можна припустити, що вперше митець з'явився на сцені театру Товариства «Руська бесіда» 4 червня 1912 р. Тож участь у репетиціях комічної опери, зважаючи на поспіх у підготовці вистави, Л. Курбас мав брати десь 3 кінця травня або ж з початку червня 1912 р. Ця обставина свідчить про те, що їхати 17 травня 1912 р. у четверту гастрольну подорож по Галичині з Гуцульським театром йому не було сенсу. Зрештою, враховуючи неймовірне бажання Л. Курбаса побувати в Красноїллі, можна припустити, що на прохання Й. Гулейчука митець міг поїхати туди у другій половині квітня або в першій половині травня, щоб провести репетиції вистав Гуцульського театру, здійснити введення на ролі нових акторів. Однак документального підтвердження цьому немає.

Для того, щоб остаточно поставити крапку у 3'ясуванні часових меж перебування Л. Курбаса в Гуцульському театрі, доведеться звернутися до самого митця, точніше, до протоколу його допиту 17 січня 1934 р., який провадив помічник начальника 2-го Секретного політичного відділу ДПУ Сидоров і якому митець заявив: «Закінчив університет 1911 року. Був призваний на військову службу. Був звільнений за кілька місяців через хворобу. 1911 року вступив до Гуцульського театру в Галичині. Працював у цьому театрі до квітня 1912 року» $[31,16]$. Власне це і є правдива відповідь Л. Курбаса дослідникам його творчості, оскільки вводити в оману слідство щодо цих дат творчої біографії не було жодного сенсу. Кількамісячна служба в австрійській армії мала тягнутися десь до пізньої осені 1911 р. I до Гуцульського театру Л. Курбас міг вступити на поклик Г. Хоткевича наприкінці 1911 р., тобто після 26 листопада, коли театр вирушив у третю подорож.

У дослідників немає одностайності щодо режисерської діяльності Л. Курбаса в Гуцульському театрі. Дивну забудькуватість гуцульських акторів, які у своїх спогадах взагалі жодним словом не згадують про Л. Курбаса, можна залишити на совісті тих, хто записував ці спогади. А проте згадане вже твердження директора i режисера Гуцульського театру О. Ремеза про те, що «режисурою Курбас не займався, а працював на посаді актора», не зовсім відповідає дійсності. Водночас не варто й перебільшувати роль Л. Курбаса у діяльності Гуцульського театру, як це зробив, наприклад, Ю. Бобошко, стверджуючи, що той, перебуваючи на посаді одного 3 режисерів цього театру, нібито «ставить найхарактерніші свої вистави "Гуцульський рік”, “Непросте”, “Прахтикований жовнір”, “Довбуш”» $[5,14]$. Натомість документально підтверджено, що всі згадані п’єси написав і поставив Г. Хоткевич, окрім його п'єси «Прахтикований жовнір», постановка якої так і залишилася нездійсненим задумом Л. Курбаса. Режисерська праця Л. Курбаса могла полягати у підтриманні цілісності вистав, введенні на ролі окремих акторів, дотриманні творчої дисципліни.

Г. Хоткевич не раз звертався до керівника театру «Березіль» Л. Курбаса з пропозицією поставити п'єсу гуцульською говіркою. Відомо, що Л. Курбас збирався здійснити на сцені цього театру постановку драми Г. Хоткевича «Довбуш». Можливо, що прагнув також втілити в життя 
свою нездійснену постановку п’єси Г. Хоткевича «Прахтикований жовнір». Так, у листі до Г. Хоткевича від 1 листопада 1926 р. Л. Курбас просить передати «гуцульські п'єси» [15].

Таким чином, свідчення Л. Курбаса та його сучасників, а також деякі інші матеріали дослідження дали можливість заповнити деякі «білі плями» в його творчій біографії. Так, 1911 рік був для 24-літнього Л. Курбаса досить важким, сповненим роздумами над сенсом життя, і ледь не став для нього останнім у житті. Це і участь у судовому процесі, пов'язаному з убивством українського студента Адама Коцка, і призов до австрійської армії та демобілізація за кілька місяців за станом здоров'я, і невдала спроба вступу до трупи театру Товариства «Руська Бесіда» та пов'язана 3 цим спроба самогубства, і закінчення Віденського університету, i, нарешті, вступ наприкінці 1911 р. до Гуцульського театру. Рік 1912 був сповнений виснажливої роботи в Гуцульському театрі, очікувань поїздки 3 цим театром у гастрольну подорож до Росії, початком праці в театрі Товариства «Руська Бесіда».

На підставі викладеного, до наукового обігу вводяться такі факти творчої біографії Леся Курбаса, пов'язані з працею в Гуцульському театрі:

- виступ на сцені Гуцульського театру у травні 1911 р. і праця в цьому театрі з кінця 1911 по квітень 1912 рр.;

- виконання в Гуцульському театрі функцій актора, режисера, передовика (організатора глядача);

- внесення до акторської скарбниці митця заголовної ролі Антося Ревізорчука («Антін Ревізорчук» Г. Хоткевича) і ролі священика («Довбуш» Г. Хоткевича) у виставах Гуцульського театру;

- прагнення очолити Гуцульський театр під час планованих його гастролей у Росії і пов'язати свою подальшу театральну діяльність 3 Наддніпрянською Україною.

Наукова новизна цієї статті полягає у тому, що на основі неспростовних фактів вперше в українському театрознавстві встановлено часові межі перебування Л. Курбаса в Гуцульському театрі, з'ясовано його функціональні обов'язки, уточнено деякі факти творчої біографії, до акторської скарбниці митця додано нові ролі, спростовано недостовірну та перекручену інформацію про нього, залучено нові джерельні матеріали. Досвід роботи Л. Курбаса в Гуцульському театрі загартував його як митця, занурив у стихію міфопоетичного світосприйняття гуцулів та їх багатої фольклорної спадщини, поглибив образне мис- лення, заклав підгрунтя для формування мистецьких устремлінь майбутнього реформатора українського театру.

\section{Джерела та література}

1. Арсенич П.Гуцульщина у творчості Гната Хоткевича / Петро Арсенич. - Івано-Франківськ : Нова Зоря, 2000. - $96 \mathrm{c}$.

2. Арсенич П. Гуцульський театр Гната Хоткевича / Петро Арсенич // Історія українського театру : у 3 т. / НАН України, ІМФЕ ім. М. Т. Рильського. - К., 2009. - Т. 2 : 1900-1945. / П. Арсенич, Л. Барабан, О. Боньковська та ін. ; [редкол. тому : Г. Скрипник (гол. ред.) та ін.] C. $147-155$

3. Арсенич П. Дорога на вершину творчості починалася 3 Гуцульського театру / Петро Арсенич // Галичина. 1997. - 25 лют.

4. Б[арнацкая] Р. Курбас Александр Степанович / Р[имма] Б[арнацкая] // Театральная энциклопедия. - М. : Советская энциклопедия, 1964. - Т. 3. - С. 337-338.

5. Бобошко Ю. Режисер Лесь Курбас / Юрій Бобошко. К. : Мистецтво, 1987. — 200 с.

6. Болабольченко А. Гнат Хоткевич / Анатолій Болабольченко. - К. : Щек ${ }^{\circ}, 2008 .-223$ с.

7. Василишин О. Меморіальний музей-садиба Леся Курбаса: нарис-путівник / О. Василишин. - Вид. 1. - Тернопіль : Укрпрінт-Захід, 2007. - 82 с. : іл.

8. Водяний Х.Спомини про Леся Курбаса (1901-1913 роки) / Х. Водяний // Лесь Курбас : Спогади сучасників ; за ред. В. С. Василька. — К. : Мистецтво, 1969. — С. 5168.

9. Волицька I. Театральна юність Леся Курбаса : (проблема формування творчої особистості) / Ірина Волицька. - Львів : Ін-т народознавства НАН України, 1995. 152 c. : фот.

10. Гарбузюк М. Початок професійної акторської діяльності Леся Курбаса: до проблеми датування / Майя Гарбузюк // Просценіум : театрознавчий журнал. - 2012. № 1-3. - С. 5-10.

11. Гірняк Й.Спомини / Йосип Гірняк ; упоряд. Б. Бойчук. Нью-Йорк : Сучасність, 1982. — 487 с.

12. Гулейчук Й. Лист до Г. Хоткевича. 11 квітня 1912 p. Музей театрального, музичного та кіномистецтва України (далі - МТМК України), від. рукоп. фондів, архів Г. Хоткевича, спр. 6693.

13. «...задивувати світ». Листи Леся Курбаса до Гната Хоткевича / публ. і вступ. стаття М. Шудрі, М. Лабінського // Соціалістична культура. - 1987. — № 2. - С. 28-31.

14. Кирчів Р. Унікальне явище українського народного театру (до 90-річчя заснування Гуцульського театру) / Роман Кирчів // Український альманах 2000. - Варшава : Об'єднання українців у Польщі, 2000. - С. 141-147.

15. Курбас Л. Лист до Г. Хоткевича. 1 листопада 1926 p. МТМК України, від. рукоп. фондів, архів Г. Хоткевича, спр. 6722.

16. Курбас Л.Лист до Г.Хоткевича. 12 квітня 1912 р. МТМК України, від. рукоп. фондів, архів Г. Хоткевича, спр. 6718.

17. Курбас Л. Лист до Г.Хоткевича. 3 квітня 1912 р. МТМК України, від. рукоп. фондів, архів Леся Курбаса, спр. 10879.

18. Курбас Л. Лист до Г. Хоткевича. 4 березня 1912 р. МТМК України, від. рукоп. фондів, архів Г. Хоткевича, спр. 6713.

19. Курбас Л.Лист до Г. Хоткевича. 9 квітня 1912 р. — МТМК України, від. рукоп. фондів, архів Леся Курбаса, спр. 10880. 
20. Курбас Лесь // Українська загальна енциклопедія «Книга знання» / під ред. д-ра І. Раковського. - Львів ; Станіславів ; Коломия : Вид. кооперативи «Рідна школа», 1932. C. $420-421$.

21. Левицький М. Премієра укр[аїнської] опери в Чернівцях / Модест Левицький // Нова Буковина. — 1912. - 16 червня.

22. Ломацький М. Лист до Г. Хоткевича. - МТМК України, від. рукоп. фондів, архів Г. Хоткевича, спр. 6652.

23. Медведик П. Курбасові весняні вечори. До 100-річчя від дня народження О. С. Курбаса / Петро Медведик // Жовтень, 1987. - № 5. - С. 81-95.

24. Панасевич-Ремез О. Лист до Ф. Погребенника. 8 травня 1959 р. - Музей Гуцульського театру Гната Хоткевича у с. Красноїлові.

25. Пилипчук Р. Гуцульський театр / Р. Я. Пилипчук // Українська Радянська енциклопедія. - Вид. 2-е. - К. : Головна редакція Української Радянської енциклопедії, 1979. T. 3. - C. 223.

26. Пилипчук Р. Театр на західноукраїнських землях / Р. Я. Пилипчук // Український драматичний театр. Нариси історії : у 2 т. / ІМФЕ ім. М. Т. Рильського АН УРСР. К. : Наукова думка, 1967. — Т. 1 : Дожовтневий період. С. 414-441.

27. Пилипчук Р. Діяльність трупи Товариства «Руська бесіда» в Галичині. Гуцульський театр Гната Хоткевича / Р. Пилипчук, П. Арсенич // Історія українського театру : у 3 т. / НАН України, ІМФЕ ім. М. Т. Рильського. — К., 2009. Т. 2 : 1900-1945 / П. Арсенич, Л. Барабан, О. Боньковська та ін. ; [редкол. тому : Г. Скрипник (гол. ред.) та ін]. C. $147-155$.

28. Рахунок Гаврила Гарасим'юка для дирекції Гуцульського театру... - МТМК України, від. рукоп. фондів, архів Г. Хоткевича, спр. 6659.

29. Ревуцький В. Нескорені березільці : Йосип Гірняк і Олімпія Добровольська / Валеріян Ревуцький. - Нью-Йорк : Об'єднання українських письменників «Слово», 1985. 201 с., 13 арк. іл.

30. Рудницький М. В наймах у Мельпомени / М. І. Рудницький. - К. : Мистецтво, 1963. - 343 с.

31. Справа № 3168 [публікація М. Лабінського і М. Шудрі архівних матеріалів щодо ув'язнення Л. Курбаса] // Україна. - 1991. - № 11. - С. 15-17.

32. Стеф'юк В.Лесь Курбас i Гуцульський театр / В. Стеф'юк // Гуцульський край. $-1997 .-31$ трав.

33. Хоткевич Г. Спогади з театральної діяльності / Гнат Хоткевич // Твори : у 2 т. / упоряд., вступ. ст. та приміт. Ф. Погребенника. - К. : Дніпро, 1966. - Т. 2. - С. 501-578.

34. Хоткевич П. 3 історії Галицького театру (Гуцульський театр р. 1911-1914) / Платоніда Хоткевич // Наші дні. 1943. - № 11.

35. Чорній С. Український театр і драматургія / С. Чорній. Мюнхен ; Нью-Йорк, 1980. — 470 с.

\section{References}

1. Arsenych, P. (2000). Huzul region in G. Khotkevych's creativity. Ivano-Frankivsk : Nova Zoria [in Ukrainian].

2. Arsenych, P. (2009). The Huzul Theatre of G. Khotkevych. History of Ukrainian Theatre : in 3 volumes. H. Skrypnyk et al. (Eds.) ; NAN Ukraine. IMFE im. M. T. Rylskoho. (Vol. 2). (pp. 147-155). Kyiv [in Ukrainian].

3. Arsenych, P. (1997). The Road to the Peak of Creativity Began From the Huzul Theatre. Halychyna, February 25 [in Ukrainian].

4. B[arnatskaia], R. (1964). Kurbas Olexander Stepanovych. Theatrical encyclopedia. (Vol. 3). (pp. 337-338). Moscow: Sovetskaya entsiklopedyia [in Russian].
5. Boboshko, Iu. (1987). Les Kurbas, a Director. Kyiv : Mystetstvo [in Ukrainian].

6. Bolabolchenko, A. (2008). Gnat Khotkevych. Kyiv : Shchek [in Ukrainian].

7. Vasylyshyn, O. ( $1^{\text {st }}$ ed.). (2007). Memorial Museum-House of Les Kurbas: essay for travellers. Ternopil : Ukrprint-Zakhid [in Ukrainian].

8. Vodianyi, Kh. (1969). Memories About Les Kurbas (1901-1913). Les Kurbas: Memories of Contemporaries. V.S. Vasylko (Ed.). (pp. 51-68). Kyiv : Mystetstvo [in Ukrainian].

9. Volytska, I. (1995). Theatrical Youth of Les Kurbas: Problem of His Personality's Forming. Lviv : In-t narodoznavstva NAN Ukrainy [in Ukrainian].

10. Harbuziuk, M. (2012). The Beginning of the Professional Actor's Career of Les Kurbas: date issues. Prostsenium: teatroznavchyi zhurnal, 1-3, 5-10 [in Ukrainian].

11. Hirniak, I. (1982). Memories. New York : Suchasnist [in Ukrainian].

12. Huleichuk, I. (April 11, 1912). Letter to G. Khotkevych. The Museum of Theatrical, Musical and Cinematographic Art of Ukraine. Manuscript of G. Khotkevych, case 6693 [in Ukrainian].

13. Shudria, M., \& Labinskyi, M. (Eds.). (1987). «...Surprise the World». Letters of Les Kurbas to Gnat Khotkevych. Sotsialistychna kultura, 2, 28-31 [in Ukrainian].

14. Kyrchiv, R. (2000). The Unique Phenomenon of Ukrainian Folk Theatre (to the $90^{\text {th }}$ Anniversary of the Huzul Theatre). Ukrainskyi almanakh 2000. (pp. 141 - 147). Warsaw : Obiednannia ukraintsiv u Polshchi [in Ukrainian].

15. Kurbas, L. (November 1, 1926). Letter to G. Khotkevych. The Museum of Theatrical, Musical and Cinematographic Art of Ukraine. Manuscript of G. Khotkevych, case 6722 [in Ukrainian].

16. Kurbas, L. (April 12, 1912). Letter to G. Khotkevych. The Museum of Theatrical, Musical and Cinematographic Art of Ukraine. Manuscript of G. Khotkevych, case 6718 [in Ukrainian].

17. Kurbas, L. (April 3, 1912). Letter to G. Khotkevych. The Museum of Theatrical, Musical and Cinematographic Art of Ukraine. Manuscript of G. Khotkevych, case 10879 [in Ukrainian].

18. Kurbas, L. (March 4, 1912). Letter to G. Khotkevych. The Museum of Theatrical, Musical and Cinematographic Art of Ukraine. Manuscript of G. Khotkevych, case 6713 [in Ukrainian].

19. Kurbas, L. (April 9, 1912). Letter to G. Khotkevych. The Museum of Theatrical, Musical and Cinematographic Art of Ukraine. Manuscript of G. Khotkevych, case 10880 [in Ukrainian].

20. Rakovskyi, I. (Ed.). (1932). Kurdas Les. Ukrainian General Encyclopedia «The Book of Knowledge». Lviv; Stanislaviv; Kolomyia : Vyd. kooperatyvy «Ridna shkola» [in Ukrainian].

21. Levytskyi, M. (1912). Premiere of the Ukrainian Opera in Chernivtsi. Nova Bukovyna, June 16 [in Ukrainian].

22. Lomatskyi, M. (n.d.). Letter to G. Khotkevych. The Museum of Theatrical, Musical and Cinematographic Art of Ukraine. Manuscript of G. Khotkevych, case 6652 [in Ukrainian].

23. Medvedyk, P. (1987). Kurbas Spring Eves. To the Anniversary of $100^{\text {th }}$ Birthday of O.S. Kurbas. Zhovten, 5, 81-95 [in Ukrainian].

24. Panasevych-Remez, O. (May 8, 1959). Letter to F. Pohrebennyk. The Museum of the Huzul Theatre of G. Khotkevych in v. Krasnoillia [in Ukrainian].

25. Pylypchuk, R. ( $2^{\text {nd }}$ ed.). (1979). The Huzul Theatre. Ukrainian Soviet Encyclopedia. (Vol. 3.). (p. 223). Kyiv : Holovna redaktsiia Ukrainskoi Radianskoi entsyklopedii [in Ukrainian]. 
26. Pylypchuk, R. (1967). Theatre in Western Ukraine. Ukrainian Drama Theatre. Essays of History: in 2 volumes. IMFE im. M. T. Rylskoho AN URSR. (Vol. 1). (pp. 414-441). Kyiv: Naukova dumka [in Ukrainian].

27. Pylypchuk, R. \& Arsnenych, P. (2009). The Activity of the Group of the Association «Ruska Besida» in Galicia. The Huzul Theatre of G. Khotkevych. History of Ukrainian Theatre: in 3 volumes. H. Skrypnyk et al. (Eds.); NAN Ukrainy, IMFE im. M. T. Rylskoho. (Vol. 2). (pp. 147-155). Kyiv [in Ukrainian].

28. The Bill of Gavryla Herasym uk to the Administration of the Huzul Theatre. (n.d.). The Museum of Theatrical, Musical and Cinematographic Art of Ukraine. Manuscript of G. Khotkevych, case 6659 [in Ukrainian].

29. Revutskyi, V. (1985). The Unbreakable Berezils: Josyp Hirniak and Olimpia Dobrovolska. New York :
Obiednannia ukrainskykh pysmennykiv "Slovo" [in Ukrainian].

30. Rudnytskyi, M. (1963). The Hired by Melpomene. Kyiv: Mystetstvo [in Ukrainian].

31. Shudria, M. \& Labinskyi, M. (Eds.). (1991). Case № 3168. [publication, dealt with the Les Kurbas imprisonment]. Ukraina, 11, 15-17 [in Ukrainian].

32. Stefiuk, V. (1997). Les Kurbas and the Huzul Theatre. Hutsulskyi krai. May 31 [in Ukrainian].

33. Khotkevych, G. (1966). Memories about the Theatrical Activity : in 2 volumes. F. Pohrebennyk (Ed.). (Vol. 2). (pp. 501-579). Kyiv : Dnipro [in Ukrainian].

34. Khotkevych, P. (1943). About the History of Galician Theatre (the Huzul Theatre (1911-1914). Nashi dni, 11 [in Ukrainian].

35. Chornii, S. (1980). Ukrainian Theatre and Drama. Munich; New York [in Ukrainian]. 